J. Clin. Chem. Clin. Biochem.

Vol. 15, 1977, pp. 513-514

\title{
The Determination of Nonesterified Fatty Acids in Blood Serum Using a Stable Cupric Reagent
}

\author{
By $A$. Stajner and J. Süva
}

Faculty of Medicine, Charles University, Institute of Pharmacology

(Director: Doc. MUDr. V. Eybl C. Sc.), Plzeñ (ČSSR)

(Received November 2, 1976/April 6, 1977)

Summary: A modification of the method for the determination of nonesterified fatty acids in blood serum using a stable cupric reagent stabilized with sodium citrate, has been developed. $33 \mathrm{~g}$ of $\mathrm{NaCl}$ are dissolved in $100 \mathrm{ml}$ of the described reagent, and its $\mathrm{pH}$ should not be additionally adjusted.

The reagent is stable for at least one year if kept in the refrigerator at $5^{\circ} \mathrm{C}$.

The determination may be done in $0.1-0.2 \mathrm{ml}$ of blood serum. The relationship between the absorbance and concentration of palmitic acid is still linear at a concentration of $2500 \mu \mathrm{mol} / \mathrm{l}$. Error of the method is $\pm 3 \%$.

\section{Die Bestimmung der nicht-veresterten Fettsäuren im Blutserum mit einem stabilen kupferhaltigen Reagenz}

Zusammenfassung: Eine Modifikation der Methode für die Bestimmung der nicht-veresterten Fettsäuren im Blutserum wurde durch Verwendung eines stabilen kupferhaltigen Reagenz ausgearbeitet.

$33 \mathrm{~g} \mathrm{NaCl}$ können in $100 \mathrm{ml}$ des besrhriebenen Reagenz gelöst werden und der pH-Wert braucht nicht nachträglich kontrolliert zu werden.

Die Reagenz ist mindestens ein $\mathrm{Jahr}$ bei $+5^{\circ} \mathrm{C}$ stabil.

Die Bestimmung kann in 0,1-0,2 ml Blutserum durchgeführt werden.

Die Beziehung zwischen der Absorption und der Konzentration der Palmitinsäure ist bis zu einer Konzentration von $2500 \mu \mathrm{mol} / 1$ linear. Der Fehler der.Methode beträgt $\pm 3 \%$.

\section{Introduction}

The original Duncombe method (1) for the photometric determination of nonesterified fatty acids was variously modified. Laurell \& Tibbling (2) increased the specific density of the cupric reagent by adding $\mathrm{NaCl}$.

The recently used cupric reagents with a high amount of $\mathrm{NaCl}$ are further modified by the addition of $\mathrm{NaOH}$ to attain a suitable $\mathrm{pH}$. Acçording to various authors they are stable for one day $(3,4)$, two weeks $(2)$, or with a higher amount of triethanolamine, for several weeks (5).

In the present study we describe a method for the determination of nonesterified fatty acids in the serum using a stable cupric reagent stabilized with sodium citrate; whose $\mathrm{pH}$ should not be additionally adjusted.

\section{Materials and Method}

\section{Reagents}

Extraction mixture: chloroform- $n$-heptane-methanol, volumes, $28 \mathrm{ml}+21 \mathrm{ml}+1 \mathrm{ml}$.

Cupric reagent: $45 \mathrm{ml}$ of $1.0 \mathrm{~mol} / 1$ triethanolamine is mixed with $5 \mathrm{ml}$ of $0.5 \mathrm{Imol} / 1$ solution of sodium citrate $\left(\mathrm{Na}_{3} \mathrm{C}_{6} \mathrm{O}_{7}\right.$. - $2 \mathrm{H}_{2} \mathrm{O}$ ) and $50 \mathrm{ml}$ of $0.267 \mathrm{~mol} / 1 \mathrm{Cu}\left(\mathrm{NO}_{3}\right)_{2} \cdot 3 \mathrm{H}_{2} \mathrm{O}$ p. a. are added. $33 \mathrm{~g}$ of $\mathrm{NaCl}$ p. a. are dissolved in $100 \mathrm{ml}$ of the reagent with the aid of an electromagnetic mixer.

Basic standard solution of palmitic acid in extraction mixture: $1000 \mu \mathrm{mol} / \mathrm{l}$.

Lead diethyldithiocarbamate: solution in chloroform - $1.0 \mathrm{~g} / \mathrm{l}$.

Procedure

$5.0 \mathrm{ml}$ of extraction mixture and $2.0 \mathrm{ml}$ of cupric reagent are added to $0.2 \mathrm{ml}$ of serum and $0.2 \mathrm{ml}$ of distilled water in the blank test. The tubes are closed with polyethylene plugs, shaked for 10 minutes in a shaker and centrifuged for 5 minutes at 
$3000 \mathrm{rev} . / \mathrm{min} ; 0.20 \mathrm{ml}$ of lead diethyldithiocarbamate solution are added to $1.5 \mathrm{ml}$ of upper organic layer. The colour intensity is measured at $440 \mathrm{~nm}$.

The working standard solutions are prepared by diluting the basic standard solution with extraction mixture. They are processed as described above, using $0.2 \mathrm{ml}$ of distilled water instead of serum.

\section{Results and Discussion}

The stability of cupric reagents with various amounts of sodium citrate at laboratory temperature increases with the increasing concentration of the sodium citrate. With $0.34-0.68 \mathrm{~mol} / \mathrm{l}$ sodium citrate the reagent is stable for about 2-3 months.

The stability of the described cupric reagent is still much higher if kept in the refrigerator at $5{ }^{\circ} \mathrm{C}$. The reagent containing $0.34-1.02 \mathrm{~mol} / 1$ sodium citrate did not present any precipitation or crystalization of any substances within the period of one year. In determining palmitic acid with the help of cupric reagents kept for one year in the refrigerator at $+5{ }^{\circ} \mathrm{C}$ there was a striking decrease of the value of absorbance of the sample when the reagent was used with $1.02 \mathrm{~mol} / \mathrm{l}$ sodium citrate. If compared with the fresh reagent in $1.02 \mathrm{~mol} / \mathrm{l}$ sodium citrate, the value of the absorbance was, on average, $30 \%$ lower (tab. 1 ).

\section{References}

1. Duncombe, W. G. (1963), Biochem. J. 88, 7-10.

2. Laurell, S. \& Tibbling, G. (1967), Clin. Chim. Acta 16, $57-62$.

3. Williamson, J. \& Scott-Finigan, T. J. (1974), Clin. Chim. Acta 57, 175-179.

4. Regouw, B. J. M., Cornelissen, P. J. H. C., Helder, R. A. P.,
Tab. 1. Dependence of absorbance in the determination of nonesterified fatty acids $(500 \mu \mathrm{mol} / \mathrm{l})$ on the concentration of sodium citrate (see Materials), using fresh cupric reagents, or 1 year old cupric reagents kept in the refrigerator at $+5^{\circ} \mathrm{C}$. Average values of $2-6$ determinations.

\begin{tabular}{lllll}
\hline $\begin{array}{l}\text { Sodium citrate } \\
\text { in mol/1 }\end{array}$ & \multicolumn{2}{c}{ fresh cupric reagents } & \multicolumn{3}{c}{$\begin{array}{l}\text { 1 year old cupric } \\
\text { reagents }\end{array}$} \\
& ASt & A $_{0}$ & ASt & A $_{0}$ \\
\hline 0.34 & 0.41 & 0.09 & 0.41 & 0.09 \\
0.51 & 0.40 & 0.08 & 0.41 & 0.09 \\
0.68 & 0.39 & 0.07 & 0.40 & 0.09 \\
0.85 & 0.38 & 0.06 & 0.37 & 0.08 \\
1.02 & 0.35 & 0.03 & 0.29 & 0.06 \\
\hline
\end{tabular}

Lead diethyldithiocarbamate was most satisfactory, with regard to stability, for the determination of cupric ions. The solution of lead diethyldithiocarbamate in chloroform may be kept for one year in the refrigerator at the given concentration.

The relationship between the absorbance and concentration of various amounts of palmitic acid is still linear at the concentration of $2500 \mu \mathrm{mol} / 1$. With an average concentration of nonesterified fatty acids in the serum of $279 \mu \mathrm{mol} / 1$, the error of the method was $\pm 3 \%$.

Spijkers, J. B. F. \& Weeber, Y. M. M. (1971), Clin. Chim. Acta 31, 187-195.

5. Noma, A., Okate, H. \& Kita, M. (1973), Clin. Chim. Acta 43, 317-320.

Dr. A. Stajner Pharmacological Institute Faculty of Medicine, Karlovarská 48 CS-30167 Plzen Czechoslovakia 